\title{
Alkylresorcinols Protect the DNA from UV-Damage In Vitro and In Vivo Models
}

\author{
Dmitry Deryabin, Olga Davydova and Irina Gryazeva \\ Orenburg State University, Department of Microbilogy \\ Russia
}

\section{Introduction}

Alkylresorcinols (AR) are a large group of secondary metabolites synthesized by bacteria [El-Registan et al., 2006], fungi [Zarnowski et al., 1999] and plants [Kozubek \& Tyman, 1999]. In microorganisms AR control many aspects of a functional and morphological differentiation [Nikolaev et al., 2006], controlling transition to the dormant state [Mulyukin et al., 2003]. Such biological activity of AR is determined by their ability to interact with a broad spectrum of biopolymers, such as membrane lipids, proteins and nucleic acids. AR interaction with membrane lipids is determined by the amphiphilic properties of these molecules and leads to an increase of cytoplasmic membrane microviscosity, changing its permeability for monovalent ions [El-Registan et al., 1979; Reusch et al., 1983] and following cell dehydration [Kaprelyants et al., 1986]. The effect of AR interaction with the enzyme proteins appears in change of the rate of catalysis [Martirosova et al., 2004] and the spectrum of substrate specificity [Petrovskii et al., 2009] with a synchronous significant increase of protein globules stability to various extreme factors [Solyanikova et al., 2011]. Results of AR interaction with biopolymers and supramolecular structures in the whole cell are the control of metabolic processes, including their inhibition and the formation of cyst-like forms of microorganisms [Nikolaev et al., 2006], characterized by increased resistance to different stress factors [Stepanenko et al., 2004].

At the same time formation of anabiotic state and increase of stress resistance of bacterial cells are suggest the stabilization of the main genetic information storage biopolymer (DNA) with the obtaining of resistance to a wide range of abiotic and biotic factors [Azam \& Ishihama, 1999; Setlow, 1995]. Due to chemical structure, alkylresorcinols are possible candidates for this role. Thus, the antimutagenic effect of AR is well described [Gasiorowski \& Brocos, 2001], as well as effect of compactisation of the nucleoid in the dormant bacterial cells [Mulyukin et al., 2005], accompanied by a change of elastic and viscous characteristics of DNA.

In our previous works the fact of AR-DNA interactions, resulting in modifications of physicochemical properties of this biopolymer with formation of supramolecular complexes has been described [Davydova et al., 2005]. The AR-DNA interactions also leads to B $\rightarrow$ A transition of DNA, increase the thermostability of these complexes and improving the resistance of DNA to some external influences [Davydova et al., 2006, 2007]. 
Much less is known about the influence of AR on DNA sensitivity to the UV irradiation, though this problem is significant because UV is an important ecological factor and also finds wide application in various medical and biological technologies. The damaging effect of UV on DNA consists in its absorption by nitrogenuos bases with the formation of intraand intermolecular cross-links [Lyamichev et al., 1990], while increasing the UV-dose causes deep degradation of the biopolymer caused by single- and double-stranded breaks [Cariello et al., 1988]. Potential effects of AR in this system are defined by their ability to absorb ultraviolet radiation in the range of 245-295 $\mathrm{nm}$ for different AR homologues, and to act as antioxidant similar to other photoprotectors [Fraikin et al., 2000]. According to accumulated data, AR are also capable to change the activity of stress regulons, including the SOS-response genes [Golod et al., 2009], that are realize an active DNA reparation at various damages.

In this reason the goal of this work is to investigate the complex effects of AR on UV sensitivity of DNA in molecular (in vitro) and cellular (in vivo) models.

\section{Materials and methods}

\subsection{Materials}

Chemically synthesized high-grade AR $(99,9 \%)$, differing in the length and an arrangement of alkyl radical (table 1), including $\mathrm{C}_{1}-\mathrm{AR}, \mathrm{C}_{5}$-AR and $\mathrm{C}_{6}$-AR (Sigma, USA), and also $\mathrm{C}_{3}-\mathrm{AR}$ and $\mathrm{C}_{12}$-AR (Enamine, Ukraine) were used in this work. The DNA length markers $\lambda /$ HindIII restricts (from 10000 down to $250 \mathrm{bp}$ ) and the plasmid pUC19 (2686 bp) were produced by SibEnzyme Ltd. (Russia). For PCR analysis DNA fragments (273 bp) of Chlamydia trachomatis were used (NPF "Liteh", Russia).

\subsection{Bacterial strain}

Escherichia coli K12 TG1 strain was used as a recipient for transformation. At studying of SOS-system activity the recombinant bioluminescent strain of Escherichia coli recA'::lux containing plasmid-borne fusions of the recA promoter-operator region to the Photorhabdus luminescens ZM 1 lux genes (GosNIIgenetika, Russia) was used. Increase of their luminescence in the presence of DNA damage factors [Rosen et al., 2000], were shown previously. Investigation of the luminescent response of this strain to UV radiation allows quantitatively estimate in a real time a SOS-system induction.

\subsection{UV light irradiation}

Preparations of DNA and bacterial suspensions irradiated using a germicidal bulb (Osram, Germany) through an optical filter of $254 \mathrm{~nm}$ with a power light exposure of $6.7 \mathrm{~W} / \mathrm{m}^{2}$ as determined by UV radiometer (TKA-PKM, Russia).

\subsection{Agarose gel electrophoresis}

DNA electrophoresis was performed in $0.8 \%$ agarose gel containing $0.5 \mu \mathrm{g} / \mathrm{ml}$ ethidium bromide in TBE buffer ( $\mathrm{pH} 7.2)$ at field strength of $5 \mathrm{~V} / \mathrm{cm}$. The agarose gel was visualized on UV transilluminator (Vilber Lourmat, France) and photographed. The received digital images were processed with use of "ImageJ" software (NIH, USA). 


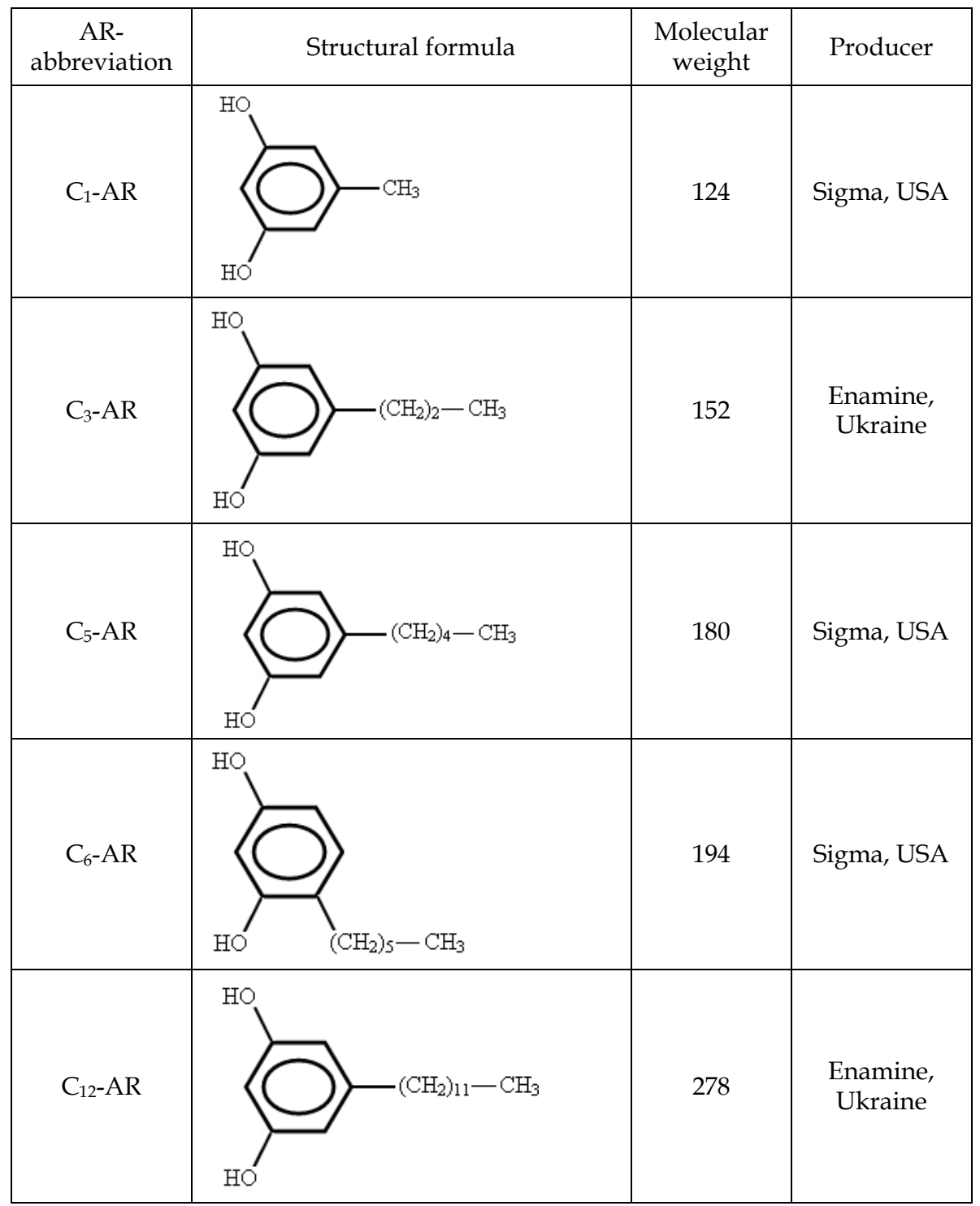

Table 1. Chemical analogs of alkylresorcinols have been used in the study

\subsection{Isolation of DNA and PCR-procedure}

DNA was isolated from the gel block using the DNA extraction kit (Cytokine, Russia). DNA added to the tube containing the reagents for PCR (DNA-Technology, Russia) and amplified in 35 cycles $\left(30 \mathrm{~s} 93^{\circ} \mathrm{C}, 30 \mathrm{~s} 59^{\circ} \mathrm{C}\right.$ and $30 \mathrm{~s}$ at $\left.72^{\circ} \mathrm{C}\right)$. For subsequent analysis $5 \mu \mathrm{l}$ of the product was analyzed by gel electrophoresis as described above. 


\subsection{Transformation}

E.coli K12 TG1 were grown to log phase (up to $\mathrm{OD}_{600}=0.20-0.30$ ) in Luria-Bertani (LB) broth, washed and ultimately concentrated 25 times in ice-cold $100 \mathrm{mM}$ of $\mathrm{CaCl}_{2}$. DNA was extracted from agarose gel after electrophoresis, added to $200 \mathrm{ml}$ of competent cell and incubated at $0^{\circ} \mathrm{C}$ for $15 \mathrm{~min}$. The cell-DNA complex was transferred to $42^{\circ} \mathrm{C}$ for exactly $90 \mathrm{~s}$ and was rapidly chilled in ice. Then $1000 \mathrm{ml}$ LB-broth was added and the cells were incubated at $37^{\circ} \mathrm{C}$ for $60 \mathrm{~min} .100 \mathrm{ml}$ cells was spread on LB-agar with and without selective marker ampicillin $(50 \mathrm{mg} / \mathrm{ml})$, to obtain the number of transformants and viable cells respectively. Plates were incubated at $37^{\circ} \mathrm{C}$ for $18-24 \mathrm{~h}$.

\subsection{Bioluminescent and microbiological methods}

E.coli rec $A^{\prime}::$ lux $C D A B E$ strain were grown for $16-18$ hours at $37^{\circ} \mathrm{C}$ in LB-broth in the presence of $20 \mu \mathrm{g} / \mathrm{ml}$ of ampicillin. Immediately before the experiment the culture was diluted 1:20 by fresh culture medium and incubated until early log-phase. The grown biomass was mixed with AR solutions in final concentrations of $10^{-5}, 10^{-4}$ и $10^{-3} \mathrm{M}$, with used for their dilution with distilled water (control) and incubated for 60 minutes. The luminescence intensity of UV-irradiated E.coli rec $A^{\prime}:: l u x$ and intact specimens were registered by plate bioluminometer LM 01T (Immunotech, Czech Rep.) in a real time. The number of viable cells was determined from the colony-forming units (CFU) on a surface of a LB-agar after the subsequent incubation within 24 hours at $37^{\circ} \mathrm{C}$. A quantitative estimation of an induction of the SOS-system calculated on formula

$$
F_{i}=\frac{\operatorname{lux} A_{i} \cdot B_{0}}{\operatorname{lux} A_{0} \cdot B_{i}}
$$

where lux $\mathrm{A}_{0}$ - light intensivity of not irradiated suspension of cells, lux $\mathrm{A}_{\mathrm{i}}$ - the light intensivity, the irradiated suspension of cells, $B_{0}$ - quantity of viable cells in not irradiated test, $B_{i}$ - quantity of viable cells in the UV-irradiated test [Tsvetkova \& Golyasnaya, 2007].

\subsection{Statistical analysis}

All studies were performed at least in triplicate and processed by variational statistic methods using "Statistica" software (StatSoft Inc., USA).

\section{Results}

\subsection{AR directly protects DNA from UV damage}

Electrophoresis of DNA phage $\lambda$ linearized by HindIII restrictase, detected 7 fragments with a fixed length from 10000 down to $250 \mathrm{bp}$ (Fig. 1 lane 1). Three hours of UV exposure with a total dose of $3.64 \mathrm{~J} / \mathrm{m}^{2}$ significantly changed the pattern of electrophoresis, leading to the disappearance of the typical bands of DNA fragments and their transformation into solid track (Fig. 1 lane 2). The cause of these changes were the multiple breaks of double-stranded DNA with disintegration of each on irregular length of the fragments.

DNA preincubation with AR didn't lead to a change in electrophoretic mobility of fragments, but affected the sensitivity to UV radiation, which depends both on the chemical structure, and 
the used concentration of AR. For example, using $10^{-3} \mathrm{M}$ of $\mathrm{C}_{1}$-AR before the UV irradiation saves on $5.9 \pm 0.6 \%$ of more DNA (Fig. 1, lane 4 ), although the use of $10^{-4} \mathrm{M}$ of $\mathrm{C}_{1}$-AR did not significantly change the electrophoretic pattern (Fig. 1 lane 3). On the other hand, the effect of long-chain $\mathrm{C}_{6}$-AR was significantly higher, which led to the protective effect even at concentration of $10^{-4} \mathrm{M}$ (Fig. 1 lane 5), and at concentration of $10^{-3} \mathrm{M}$ it had been protected up to $22.4 \pm 1.7 \%$ in the presence of $\mathrm{C}_{6}$-AR under the same conditions (Fig. 1 lane 6).

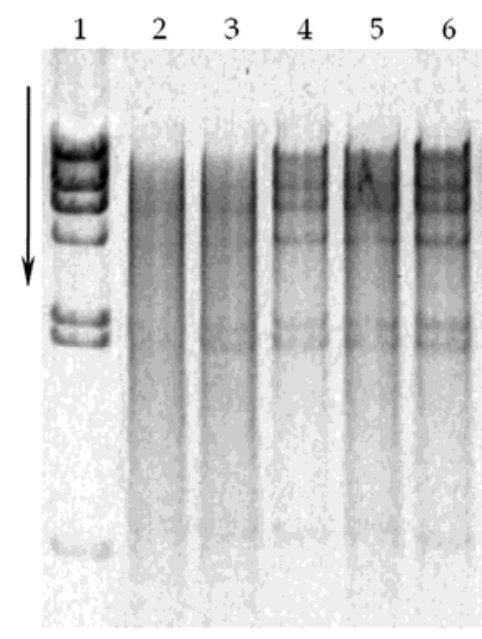

A

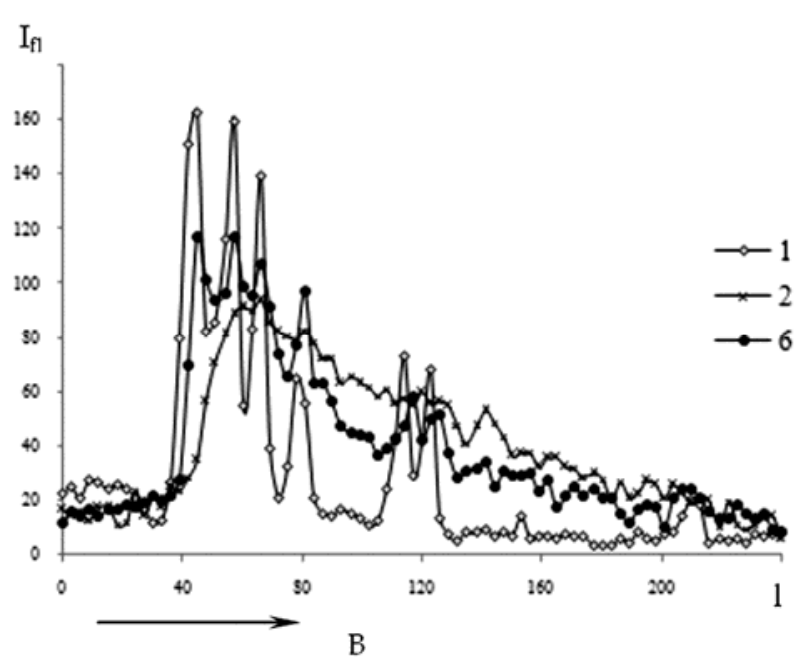

B

Fig. 1. Electrophoretic mobility of Hind III-restrict fragments of $\lambda$ DNA after UV irradiation (A) and DNA electrophoregram trace (B): 1 - control, 2 - after UV irradiation for 3 hours $\left(3.64 \mathrm{~J} / \mathrm{m}^{2}\right), 3,4$ - the same in the presence of $\mathrm{C}_{1}$-AR in concentrations of $10^{-4} \mathrm{M}$ and $10^{-3} \mathrm{M}, 5$, 6 - the same in the presence of $\mathrm{C}_{6}$-AR at concentrations of $10^{-4} \mathrm{M}$ and $10^{-3} \mathrm{M}$. The arrow shows the migration vector.

The result of pUC19 plasmid DNA electrophoresis has allowed to detect the presence of two DNA conformations: supercoiled circular form (I) that accounts for $60.4 \%$ of the total DNA amount and relaxed circular form (II), accounts for 39.6\% (Fig. 2 lane 1). UV irradiation of this plasmid in 30 minutes with a total dose of $0.61 \mathrm{~J} / \mathrm{m}^{2}$ changed the relative intensity of the typical bands, reflecting their conformational changes. It was exhibited by disappearance of a typical band I and parallel temporary increase of band II intensity that was the result of the transition of supercoiled plasmid DNA form into the relaxed supercoiled form caused by single-stranded breaks. The second effect was the appearance of the band III, which was interpreted as the result of a transition of supercoiled DNA molecules into the linearized form as a result of the formation one double-stranded breaks (Fig. 2 lane 2). The total number of electrophoretically detectable DNA after UV irradiation was $83.6 \pm 4.1 \%$ of its initial content in the sample. Increasing of UV-dose up to $3.64 \mathrm{~J} / \mathrm{m}^{2}$ induced massive damage of plasmid DNA with the formation of a track from variable molecular weight linear fragments, as well as in the case of phage $\lambda$ DNA (data is not shown).

Incubation of the pUC19 plasmid in the presence of AR prevented the formation of these effects, also depending on the chemical structure of used AR. So on the one hand, the 
amount of DNA after UV irradiation in the presence of $10^{-3} \mathrm{M} \mathrm{C}_{1}$-AR was $91.9 \pm 2.6 \%$; in the presence of $\mathrm{C}_{6}$-AR at the same concentration- $93.6 \pm 3.1 \%$, and in the presence of $\mathrm{C}_{12}-\mathrm{AR}$ $95.0 \pm 3.4 \%$ if compared with samples of intact DNA molecules (Fig. 2B). On the other hand, on the conformational transitions of plasmid DNA in the presence of AR was also less expressed. In particular, long-chain $\mathrm{AR}: \mathrm{C}_{6}-\mathrm{AR}$ and $\mathrm{C}_{12}-\mathrm{AR}$ almost completely prevents the appearance of band III (no more than 1.2\% in comparision with irradiated DNA and kept the initial supercoiled conformation (lane I) as $87.3-98.7 \%$ of unirradiated DNA. Short-chain $\mathrm{C}_{1}$-AR and $\mathrm{C}_{3}$-AR slightly protected DNA from the formation of single- and doublestranded breaks so the DNA amount in the II and III bands corresponded to the irradiated DNA probes. Though they prevented the deeper DNA degradation with the preservation of quantity of initial supercoiled conformation (band I) in 1.1 times more in comparison with the UV-irradiated control.

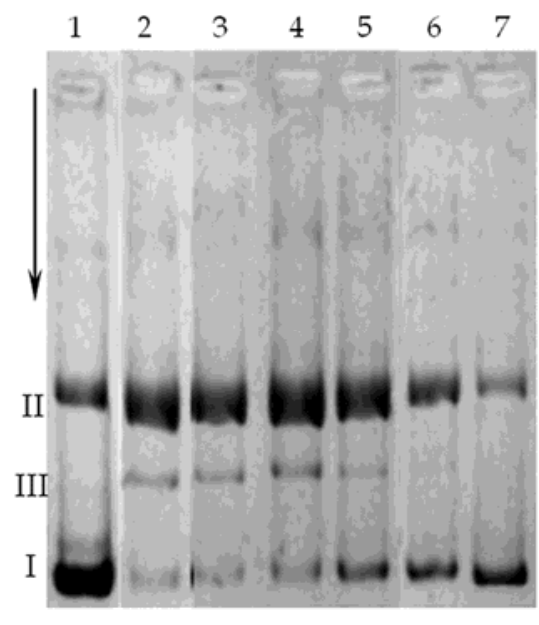

A

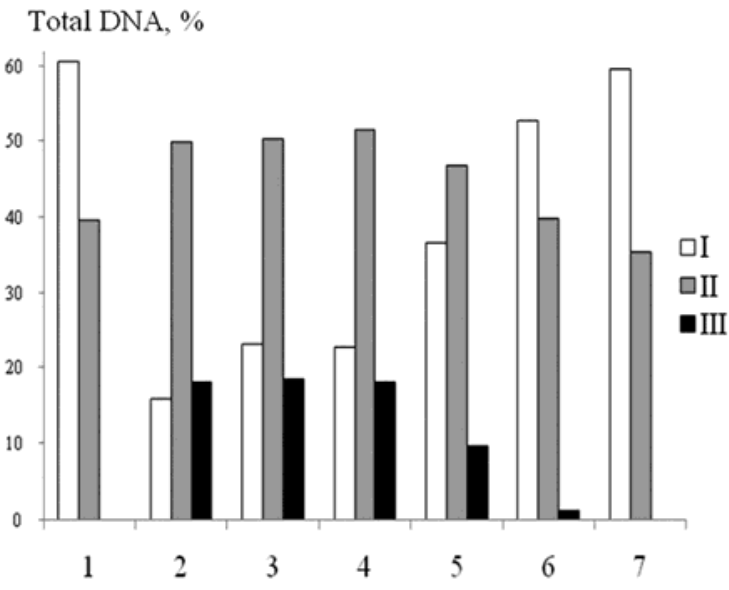

B

Fig. 2. Electrophoretic mobility of pUC19 DNA after UV irradiation (A) and relative DNA content (B) in the bands I-III for the lanes: 1 - control, 2 - after UV irradiation for $30 \mathrm{~min}(0.61$ $\left.\mathrm{J} / \mathrm{m}^{2}\right), 3$ - then the same in the presence of $10^{-3} \mathrm{M} \mathrm{C}_{1}-\mathrm{AR}, 4-\mathrm{C}_{3}-\mathrm{AR} 5-\mathrm{C}_{5}-\mathrm{AR}, 6-\mathrm{C}_{6}-\mathrm{AR}, 7$ $\mathrm{C}_{12}-\mathrm{AR}$. The arrow shows the migration vector.

Thus, the AR directly protect DNA from the UV-damage. This is manifested in the saving of the total amount of this biopolymer, preventing its deep degradation due to formation of double-stranded breaks, as well as preventing the single -stranded breaks without transition of supercoiled into the relaxed circular form of DNA. Evidence of effects increased with length of the alkyl radical of the AR molecule and with AR concentration increase.

\subsection{DNA protection by AR during agarose gel electrophoresis detection}

The founded results formed the basis for the development of technology of DNA protection against the UV-damaging effect during the detection of gel electrophoresis results. The Actuality of this problem is the need to preserve the structural integrity of DNA for diagnostic studies using DNA technology, as well as saving of functional characteristics of 
the biopolymer for subsequent genetic engineering manipulations [Cariello et al., 1988; Hartman, 1991]. Known methods of DNA protection from UV radiation during the separation and detection are using such UV protectors as nucleosides [Grendemann \& Schumig, 1996] or zinc-imidazole salts [Sosa et al., 1996] that are injected into the system for electrophoresis by different ways. Against this background, the identification of AR activity as photoprotectors determines the prospects for their use for this purpose. Availability of the approach is confirmed by well-known experience of AR using in the chemical industry as UV-protectors for rubber and plastics [Vagel \& Roo, 2004].

As has been shown above photorotective effects are most expressed in long-chain $\mathrm{C}_{6}$-AR and $\mathrm{C}_{12}$-AR. However, some technological aspects are determined by low $\mathrm{C}_{12}-\mathrm{AR}$ solubilization in water, demanded its preliminary dissolution in ethanol that gave additional difficulties for AR addition into different media for electrophoresis. For this reason, in the current paragraph of the study $\mathrm{C}_{6}$ - $\mathrm{AR}$ was used, photoprotective effects of wich were compared with $C_{1}-A R, C_{3}-A R$ and $C_{5}-A R$.

The first DNA preparations in this part of the study was PCR product - DNA of Chlamydia trachomatis $(273 \mathrm{bp})$, in the presence of a smaller by molecular mass internal control of human DNA. After migration the gel was exposured for 5, 30, 300 and 600 seconds by transilluminator Vilber Lourmat, equipped with $6 \mathrm{UV}$ lamps with irradiance $\mathrm{W}=0,24$ $\mathrm{W} / \mathrm{m}^{2}$ and $254 \mathrm{~nm}$ filter. The degree of structural integrity loss of amplificated DNA was evaluated by the decrease of brightness intensity of the of the bands processed by using the tools of "ImageJ" computer program.

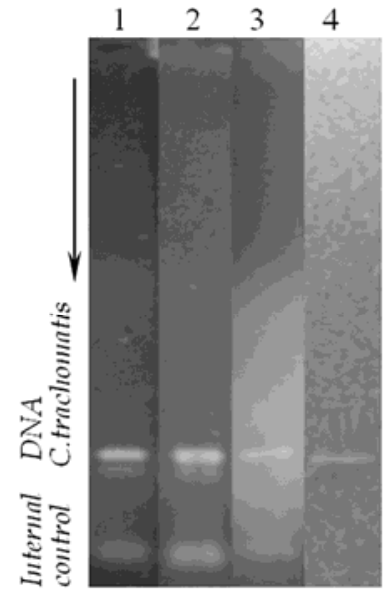

A

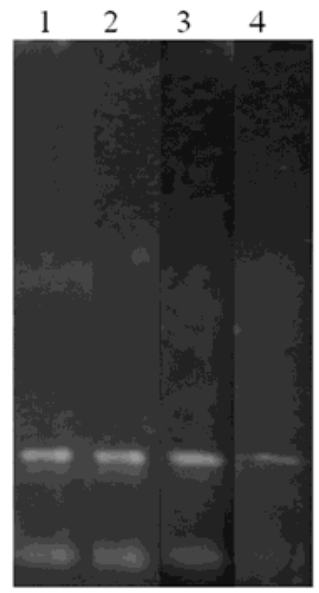

B

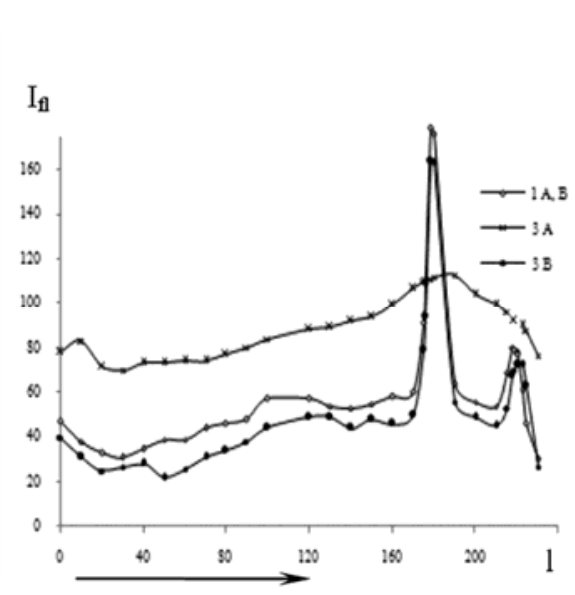

C

Fig. 3. Agarose gel after electrophoretic separation of amplified DNA of Chlamydia trachomatis without $(\mathrm{A})$, and with the addition of $\mathrm{C}_{6}-\mathrm{AR}(\mathrm{B})$ in the electrophoretic system at exposure by transilluminator at $254 \mathrm{~nm}$ for 5 (1), 30 (2), 300 (3) and 600 (4) seconds, and profiles of the electrophoretic mobility (C).

DNA exposure by transilluminator for 5-30 seconds has allowed to visualize the band that consist of amplified DNA fragments of C. trachomatis (Fig. 3 lane 1,2). The subsequent 
increasing of exposure up to 300 seconds resulted in a reduction of the relative emission intensity of this band (Fig. 3C) associated with photodamage both DNA molecules, and the development of luminescence of the gel, creating a backlight (Fig. 3B, lane 3). Finally, there were only trace amounts of this band after 600 seconds of irradiation (Fig. 3B, lane 4) which were not detected by the using software. In such situation, taking a right diagnostic conclusion was impossible.

On this background, the use of $\mathrm{C}_{6}$-AR stabilized the gel pattern, preserving both DNA degradation and optical properties (transparency and coloration) of agarose. Thus, if at minimal exposure time of 5-30 seconds, there were no significant expressed differences of bands if compare with the control (Fig. 3B lane 1,2), then after 300 seconds, the luminescence of C. trachomatis DNA was much higher (up to $28.4 \%$ ) than ones in control, and did not differ from baseline (88.9\% - Fig.3C). On the other hand, another $\mathrm{C}_{6}$-AR effect was optical properties saving while preserving the characteristics of the background (Fig. 3B lane 3). Moreover, with increasing of exposure time up to 600 seconds, registration of the results with software was still possible (Fig.3B lane 4).

The used variants of $\mathrm{C}_{6}$-AR application were: adding to the wells of the gel to DNA, directly bringing into the agarose gel and the addition to electrophoretic buffer. The use of the latest way demonstrated its greatest efficiency by saving up to 1.63 times more DNA preparations if compared with the standard method of electrophoresis, while other ways showed $15.45 \%$ increase when $\mathrm{C}_{6}$-AR was introduced into an agarose gel and $1.63 \%$ - when added to the DNA preparations.

A quantitative comparison of DNA band intensity at adding of different AR homologues into the buffer after 300 seconds of irradiation on the transilluminator has allowed to obtain a more detailed information about the structural integrity of DNA, depending on the AR concentration (Table 2). It was found that $\mathrm{C}_{6}$-AR protected DNA greater than 1.5 -fold in the range of $10^{-3} \mathrm{M}$ and $5 \times 10^{-3} \mathrm{M}$, with a maximum effect $(163.5+15.2 \%)$ at concentrations of $10^{-}$ ${ }^{3} \mathrm{M}$. On this background, $\mathrm{C}_{1}-\mathrm{AR}$ and $\mathrm{C}_{3}-\mathrm{AR}$ demonstrated poor photoprotective activity and $\mathrm{C}_{5}$-AR showed a similar protective effect only at concentration of $10^{-3} \mathrm{M}$.

\begin{tabular}{|l|c|c|c|c|}
\hline \multirow{2}{*}{$\begin{array}{c}\text { Concentration of } \\
\text { AR, M }\end{array}$} & \multicolumn{4}{|c|}{ AR-abbreviation } \\
\cline { 2 - 5 } & $\mathrm{C}_{1}$-AR & $\mathrm{C}_{3}$-AR & $\mathrm{C}_{5}$-AR & $\mathrm{C}_{6}$-AR \\
\hline $10^{-4}$ & $68.0 \pm 15.4$ & $87.2 \pm 7.9$ & $101.3 \pm 9.3$ & $118.7 \pm 15.6$ \\
\hline $5 \times 10^{-4}$ & $97.1 \pm 9.8$ & $109.1 \pm 10.6$ & $128.1 \pm 13.3$ & $135.0 \pm 13.7$ \\
\hline $10^{-3}$ & $133.2 \pm 12.7$ & $132.7 \pm 12.3$ & $150.3 \pm 14.8^{*}$ & $163.5 \pm 15.2^{*}$ \\
\hline $2 \times 10^{-3}$ & $124.2 \pm 12.3$ & $129.1 \pm 13.2$ & $109.3 \pm 10.1$ & $153.5 \pm 13.2^{*}$ \\
\hline $5 \times 10^{-3}$ & $126.9 \pm 13.5$ & $119.2 \pm 10.8$ & $90.2 \pm 8.5$ & $142.6 \pm 14.8^{*}$ \\
\hline
\end{tabular}

Table 2. DNA protection efficiency in comparision with the control (\%) in the presence of various alkylresorcinols at UV-irradiation for 300 seconds. * $-\mathrm{P}<0.05$. 
$\mathrm{C}_{6}$-AR also preserved the DNA functional properties for genetic engineering manipulations or amplification. For example, the efficiency of PCR-amplification of $\mathrm{C}_{6}$-AR-treated DNA in comparison with UV-damaged control was significantly higher. Another result was the preservation of functional properties of DNA for transformation procedure. So, after the adding of the $\mathrm{C}_{6}$-AR in the electrophoretic buffer in a concentration of $10^{-3} \mathrm{M}$ and electrophoretic separation of pUC19 plasmid, its supercoiled form from agarose was extracted under visual control on the transilluminator for 30 seconds for transformation of bacterial E. coli cells. The transformation efficiency, expressed in a quantity of colonies of transformants was up $24.6 \%$ in comparision with the control.

On this base was developed a method for photoprotection of the DNA from the UVdamage $(\lambda=254 \mathrm{~nm})$ at detection of gel electrophoresis results, which consists in the fact that prior to the separation of DNA molecules in electrophoretic buffer is added $\mathrm{C}_{6}$-AR at concentrations of $10^{-3} \mathrm{M}$. The main positive result of a this laboratory technology is the long saving of DNA from the damaging effects of UV radiation with a prolonged preservation of its structural integrity essential for the making of diagnostic deceision and functional activity of this biopolymer that is necessary for genetic engineering manipulations.

\subsection{Bacterial cells UV protection by AR}

The result about DNA protection in vitro models has given a study problem of photoprotective AR actions of the whole bacterial cells (in vivo). The model object for this study was E.coli strain carrying prec $A^{\prime}:: l u x C D A B E-A m p^{R}$ plasmids with a cassette of luxgenes of luminescent soil bacteria Photorhabdus luminescence ZM 1, cloned under the promoter of recA E. coli gene. Such a genetic design allows to characterize quantitatively the activity of SOS-reparation system after UV irradiation which are directly proportional to the intensity of DNA damage.

UV irradiation of this bacterial cells using a broadband mercury-quartz lamp through an interference filter (bandwith $254 \mathrm{~nm}$ ), provided preferential DNA damage with minimal effects on other subcellular structures. The exposure time ranged from 0 to 180 minutes in increments of 60 minutes, which gave total dose of UV exposure 1.21, 2.43 and $3.64 \mathrm{~J} / \mathrm{m}^{2}$.

Thus, the dose of UV radiation in the range from 0 to $1.21 \mathrm{~J} / \mathrm{m}^{2}$ led to expressed growth of the absolute bioluminescence intensity of the probe with a maximum of 2.65 fold larger than background level. In turn, further increasing of dose resulted in a progressive decrease of the absolute bioluminescence intensity down to the initial values at a dose of $3.64 \mathrm{~J} / \mathrm{m}^{2}$ (Fig. 4). This effect depending on dose of UV-irradiation and developing in time effect has been caused by the loss of bacterial cells viability that has been shown in growth-test of analyzed probes on agar nutrient plates (Fig. 4).

On this background the dividing of absolute bioluminescence intensity to viable bacterial cells quantity gave the relative index $\mathrm{F}_{\mathrm{i}}$, showing proceeding activation of a DNA reparation with maximum value $F_{i}=282.85$ at highest dose of the UV-irradiation (Fig. 4).

Another starting point was a data of the alkylresorcinols action on luminescense and viability of E.coli recA'::lux cells registered a partial dependence of this effects on AR chemical structure and concentrations. 
Thus, none of the used AR homologues did not cause significant increase of the absolute level of bioluminescence, but causing its significant depression (Fig. 5). This effect increased in the range $\mathrm{C}_{1}$ - $\mathrm{AR} \rightarrow \mathrm{C}_{3}-\mathrm{AR} \rightarrow \mathrm{C} 5$ - $\mathrm{AR} \rightarrow \mathrm{C}_{6}$ - $\mathrm{AR} \rightarrow \mathrm{C}_{12}-\mathrm{AR}$, at the same time had direct concentration dependency (Fig. 5). In turn, the analysis of E.coli recA'::lux, incubated in contact with the AR shown the codirectionality between intensity of bioluminescence reduction and the CFU quantity, determined by the growth-repressed activity of these molecules (Fig.5B) [Grendemann \& Schumig, 1996]. Finally, based on these data calculation of the relative index $\mathrm{F}_{\mathrm{i}}$ allowed to reveal poorly expressed induction/inhibition of SOSsystem as a result of AR exposure (Fig.5C). So, these factors at a concentration of $10^{-5} \mathrm{M}$, leading to the induction of stress response of bacterial cells [Golod et al., 2009], accompanied

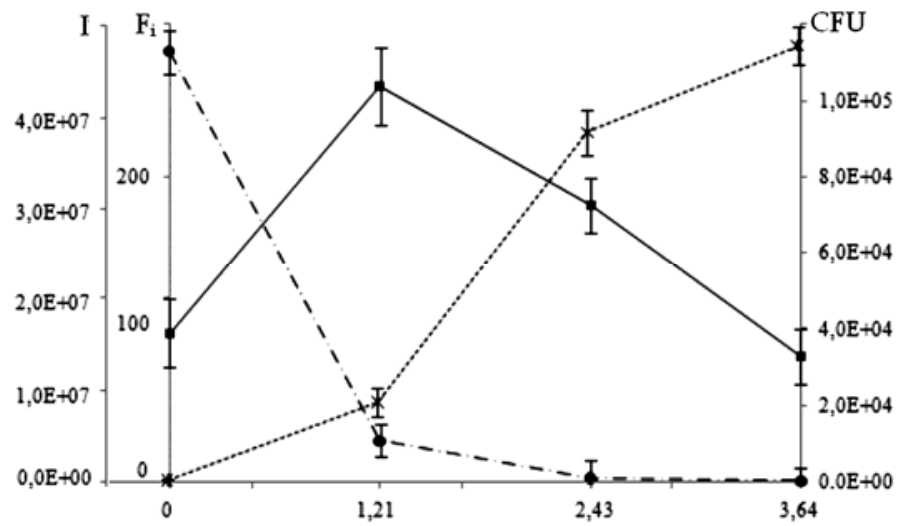

Fig. 4. Response of E.coli recA'::lux strain on UV exposure (on the horizontal axis - the exposure dose, $\left.\mathrm{J} / \mathrm{m}^{2}\right): \rightarrow-$ the absolute intensity of bioluminescence $(\mathrm{I}) ;-\bullet-{ }^{-}$the number of viable cells $(\mathrm{CFU}) ;-\cdots *---$ the relative index of induction SOS-response $\left(\mathrm{F}_{\mathrm{i}}\right)$.

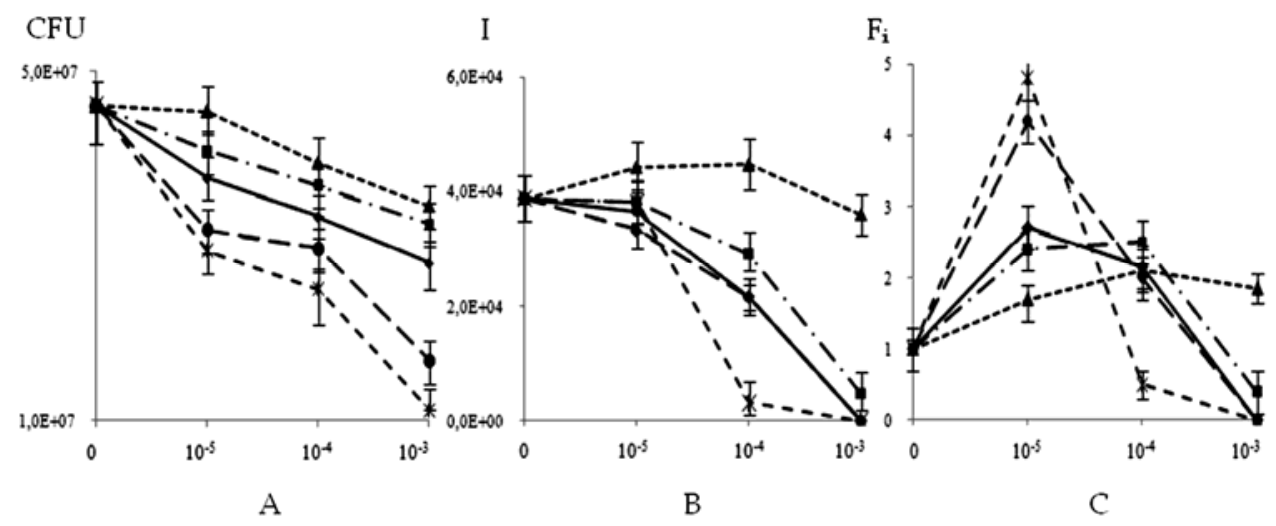

Fig. 5. E.coli recA'::lux strain response on AR action (horizontal axis - concentration, $M$ ): the number of survived cells (A), the absolute intensity of bioluminescence (B), the relative value of induction index of SOS-response (C). $\cdots-C_{1}-A R,---C_{3}-A R, \longrightarrow-C_{5}-$ $\mathrm{AR},-\bullet---\mathrm{C}_{6}-\mathrm{AR},--$ - -- $-\mathrm{C}_{12}-\mathrm{AR}$. 
by the little activation of E.coli recA'::lux relative bioluminescence intensity. On the other hand, a high $10^{-3} \mathrm{M}$ concentration, leading to the formation of the bacterial cell anabiotic state [Suzina et al., 2006], caused intensive SOS-response depression. The intermediate AR concentration $10^{-4} \mathrm{M}$ caused a minimal change of this activity, making a best opportunity for the subsequent evaluation of the combined action of the studied factors.

The study of viability, bioluminescence and SOS-system activation index at UV exposure of E.coli recA'::lux pre-incubated has allowed to characterize some of interconnected effects characterizing the protective action of AR at UV irradiated cells. Thus, the number of E.coli rec $A^{\prime}::$ lux cells, incubated in contact with the AR in a concentration of $10^{-4} \mathrm{M}$ and saved their viability after subsequent UV exposure increased in the range $C_{1}$-AR $\rightarrow C_{12}-$ $\mathrm{AR}$, at maximal dose of UV irradiation 2.0-14.4 times exceeded the value of control exposed - only to UV action (Table 3). In turn, reduction of AR concentrations down to 10${ }^{5} \mathrm{M}$, or an increase up to $10^{-3} \mathrm{M}$ accompanied by a corresponding weakening or strengthening of such a UV-protective effect. These data are well corresponding with earlier findings, characterizing the alkylresorcinols as factors that protect the bacteria and yeast cells from the ultraviolet and ionizing radiation [El-Registan et al., 2005; Il'inskaya et al., 2002; Stepanenko et al., 2004].

On the other hand, comparative analysis of $F_{i}$ variables gave the relative reduction of SOS-response in preincubated with AR bacterial cells (Table 3). So, repression SOS-response was proportionally to the length of the $A R$ alkyl radical and was $F_{i}=3.7$ (for $C_{6}-A R$ ) and $F_{i}=$ 7.0 (for $\mathrm{C}_{12}$-AR) that 76.43-40.40 fold lower than the SOS-system activation level in cells exposured only by UV radiation. With reduction of the AR concentration to $10^{-5} \mathrm{M}$ is still observed statistically significant differences in the values of induction index $\left(\mathrm{F}_{\mathrm{i}}\right)$ of the control and experimental samples, although the repression of SOS-response was less expressed. An increase of the AR concentration up to $10^{-3} \mathrm{M}$ in the case of $C_{1}-A R$ and $C_{3}-A R$ led to some suppression, and for the $\mathrm{C}_{5^{-}}, \mathrm{C}_{6}$ - and $\mathrm{C}_{12}$-AR to increase the values of $\mathrm{F}_{\mathrm{i}}$.

\begin{tabular}{|c|c|c|}
\hline AR-abbreviation & $\begin{array}{c}\text { The residual quantity of CFU } \\
\text { (\% of control: only the UV } \\
\text { radiation) }\end{array}$ & $\begin{array}{c}\text { Factor of SOS-system } \\
\text { induction }\left(\mathrm{F}_{\mathrm{i}}\right)\end{array}$ \\
\hline $\mathrm{C}_{1}$-AR & $0.6 \pm 0.1$ & $234.9 \pm 21.0$ \\
\hline $\mathrm{C}_{3}-\mathrm{AR}$ & $1.0 \pm 0.1^{*}$ & $141.9 \pm 13.3^{*}$ \\
\hline $\mathrm{C}_{5}-\mathrm{AR}$ & $1.9 \pm 0.1^{* *}$ & $38.3 \pm 3.5^{* *}$ \\
\hline $\mathrm{C}_{6}-\mathrm{AR}$ & $2.7 \pm 0.2^{* *}$ & $3.7 \pm 0.3^{* *}$ \\
\hline $\mathrm{C}_{12}$-AR & $4.3 \pm 0.2^{* *}$ & $7.0 \pm 0.6^{* *}$ \\
\hline Control $^{*}$ & $0.3 \pm 0.1$ & $282.8 \pm 26.5$ \\
\hline
\end{tabular}

Table 3. Effect of AR concentration $10^{-4} \mathrm{M}$ on the saving of E.coli $r e c A^{\prime}::$ lux cell viability and relative index of SOS-system induction at $\mathrm{UV}$ exposion $\left(3.64 \mathrm{~J} / \mathrm{m}^{2}\right){ }^{*}{ }^{*} \mathrm{P}<0.05$; ${ }^{* *}-\mathrm{P}<0.01$. 
This demonstrated that the AR realize a special mechanism of bacterial cells saving from UV-irradiation, connected with their action on "passive" and "active" DNA protection mechanisms. Probably it is based on direct interaction of AR with DNA, leading to the resistance of such comlexes to a wide range of stressors, with the simultaneous modification of the transcriptional activity of SOS-regulon. In tgis system a "passive" mechanism reduced the damage of DNA under UV irradiation and led to slower activation of SOS-system involving in "active" reparation of this biopolymer. This gave the opportunity to save viability of bacterial cells under UV irradiation at the minimal values of the repair processes activity. This results characterized AR induced resistance and SOS-repairation as two alternative "passive" and "active" mechanisms, evolutionary destined for the protection at different intensities of UV irradiation.

\section{Conclusions}

Deoxyribonucleic acid (DNA) is a very important biopolymer with the function of storage and transmission of genetic information. In this reason the protection of structural integrity and functional activity of DNA is essential for the viability of living systems, as well as the effectiveness of laboratory DNA-technics.

In turn, an important factor that can damage DNA in nature or at performing molecular genetic studies, is ultraviolet (UV) radiation that is absorbed by this biopolymer at bandwidth maxmum $254 \mathrm{~nm}$. This led to the formation of different DNA photodamages, with increasing of the dose of UV radiation progressed from pyrimidine dimers to singleand double-stranded breaks [Cariello et al., 1988; Lyamichev et al., 1990].

In this paper we describe a new nature-determined and chemically-mediated DNA protection mechanism provided by a specific group of phenolic lipids - alkylresorcinols. These molecules are synthesized by bacteria, fungi and plants [El-Registan et al., 2006; Kozubek \& Tyman, 1999; Zarnowski et al., 1999] and had different functions [Nikolaev et al., 2006], including the control of microorganisms transition in a dormant state [Mulyukin et al., 2003]. An important requirement for this process is the preservation and stabilization of a wide range of itracell biological macromolecules, including DNA [Solyanikova et al., 2011; Stepanenko et al., 2004]. This suggesting the role of AR in the protection of the biopolymer from UV exposure.

On the basis of previously determined AR-DNA interaction [Davydova et al., 2005] in this study the increasing of UV-resistance of this complex is shown. In particular, the interaction of AR with linear DNA molecules leads to biopolymer protection against deep degradation caused by UV exposure with double-stranded breaks prevention. The effect of long-chain $\mathrm{C}_{6}$ - $\mathrm{AR}$ if compared with $\mathrm{C}_{1}$-AR was expressed and increased with AR concentration. In case of contact of AR with circular molecules, it is additionally shown prevention of the transition of supercoiled molecules into circular form as a result of single-stranded breaks. Thus simultaneous use of a wide range of AR homologs confirmed the maximum effect in long $\mathrm{C}_{6}$ - and $\mathrm{C}_{12}$-AR.

This data led to the development of the original method of protecting the DNA from the damaging effects of UV radiation with a wavelength $\lambda=254 \mathrm{~nm}$ for detection of the results of gel electrophoresis. It is demonstrated the benefits of the adding of the C6-AR in 
the buffer solution compared to other ways of introducing an electrophoretic system (adding to the wells with DNA or agarose gel) and justify the optimal concentration of $\mathrm{C}_{6^{-}}$ $\mathrm{AR}$ as $10^{-3} \mathrm{M}$, which provides maximum protection of the biopolymer. The achieved result was the stabilization of DNA electrophoretic separation pattern during the detection of PCR-result. This was accompanied by stabilization of the optical properties (transparency and coloration) of the agarose gel that was used for DNA separation. On the other hand, the introduction of the $\mathrm{C}_{6}$-AR retained and functional characteristics of the shared DNA, which increased the effectiveness of subsequent E.coli cells transformation by these molecules.

Study of the action of AR on E. coli precA'::luxCDABE-AmpR has confirmed it photoprotective effects and has shown features of such activity in live systems. Surprising was the interrelation between preservation of viability of AR-processed bacterial cells in the conditions of a long and intensive UV-irradiation and depression of activity their reparing SOS-systems. It has assumed AR action and the SOS-answer as alternative "passive" and "active" mechanisms for protection of bacterial cells DNA at various intensivity of UVirradiation.

So this research reveals new mechanisms of bacterial autoregulation under extreme conditions, controlled by low weight molecules - alkylresorcinols. It applied aspects are defined by developing of methods for DNA protection in vitro and elongators of bacterial cells viability at UV exposure.

\section{Acknowledgment}

This work was supported by Federal Target Program "Research and scientific-pedagogical personnel of innovative Russia" for 2009-2013 years (№ P327). We thank Hike Nikiyan for skillful technical assistance.

\section{References}

Azam, T., Ishihama, A. Twelve species of the nucleoid-associated protein from Escherichia coli. Sequence recognition specificity and DNA binding affinity. The Journal of Biological Chemistry, Vol.274, No.46, (November 1999), pp. 33105-33113, ISSN 0021-9258

Cariello, N., Keohavong, P., Sanderson, B., Thilly, W. DNA damage produced by ethidium bromide staining and exposure to ultraviolet light. Nucleic Acids Research, Vol. 16, No.9, (May 1988), pp. 4157-4161, ISSN 0305-1048

Davydova, O., Deryabin, D., Nikiyan, A., El-Registan, G. Mechanisms of interaction between DNA and chemical analogues of microbial anabiosis autoinducers.

Davydova, O., Deryabin, D., El-Registan, G. Influence of chemical analogues of microbial autorgulators on the sensitivity of DNA to UV radiation. Microbiology, Vol.75, No.5, (September 2006), pp. 654-661, ISSN 1350-0872

Davydova, O., Deryabin, D., El-Registan, G. IR spectroscopic research on the impact of chemical analogues of autoregulatory $\mathrm{d} 1$ factors of microorganisms on structural changes in DNA. Microbiology, Vol.76, No.3, (June 2006), pp. 266-272, ISSN 13500872 
El-Registan, G., Duda, V., Kozlova, A., Duzha, M., Mityushina, L., Poplaurhina, O. Changes in constructive metabolism and ultrastructural organization of Bacillus cereus cells under the action of a specific autoregulatory factor. Microbiology, Vol.48, No.2, (February 1979), pp.240-244, ISSN 1350-0872

El-Registan, G., Mulyukin, A., Nikolaev, Yu., Stepanenko, I., Kozlova, A., Martirosova, E., Shanenko, E., Strakhovskaya, M., Revina, A. The role of microbial low-molecularweight autoregulatory factors (alkylhydroxybenzenes) in resistance of microorganisms to radiation and heat shock. Advances in Space Research, Vol.36, No.9, (2005), pp. 1718-1728, ISSN 0273-1177

El-Registan, G., Mulyukin, A., Nikolaev, Yu., Suzina, N., Galchenko, V., Duda, V. Adaptogennye functions extracellular autoinducers microorganisms. Microbiology, Vol.75, No.4, (August 2006), pp. 446-456, ISSN 1350-0872

Fraikin, G., Strakchovskaya, M., Rubin, A. Light-induced processes of cell protection against photodamage. Biochemistry, Vol.65, No.6, (June 2000), pp. 865-875, ISSN 0006-2979

Gasiorowski, K., Brocos, B. DNA repair of hydrogen peroxide-induced damage in human lymphocytes in the presence of four antimutagens. A study with alkaline single cell gel electrophoresis (comet assay). Cellular \& Molecular Biology Letters, Vol.6, (2001), pp. 897-911, ISSN 1425-8153

Golod, N., Loiko, N., Gal'chenko, V., Nikolaev, Y., El'-Registan, G., Lobanov, K., Mironov, A., Voieikova, T. Involvement of alkylhydroxybenzenes, microbial autoregulators, in controlling the expression of stress regulons. Microbiology, Vol.78, No.6, (September 2009), pp. 678-688, ISSN 1350-0872

Grendemann, D., Schumig, E. Protection of DNA during preparative agarose gel electrophoresis against damage induced by ultraviolet light. BioTechniques, Vol.21, No.5, (November 1996), pp. 898-903, ISSN 0736-6205

Hartman, P. Transillumination can profoundly reduce transformation frequencies. BioTechniques, Vol.11, No.6, (December 1991), pp. 747-748, ISSN 0736-6205

Il'inskaya, O., Kolpakov, A., Schmidt, M., Doroshenko, E., Mulyukin, A., El-Registan, G. The role of bacterial growth autoregulators (alkyl hydroxybenzenes) in the response of Staphylococci to stress. Microbiology, Vol.71, No.1, (January 2002), pp.23-29, ISSN 1350-0872

Kaprelyants, A., Suleimenov, M., Sorokina, A., Deborin, G., El-Registan, G., Stoyanovich, F., Lille, Yu., Ostrovsky, D. Structural-functional changes in bacterial and model membranes induced by phenolic lipids. Biological membranes, Vol.4, No.3, (March 1987), pp. 254-261, ISSN 0748-8653

Kozubek, A., Tyman, J. Resorcinolic lipids, the natural non-isoprenoid phenolic amphiphiles and their biological activity. Chemical Reviews, Vol.99, No.1. (January 1999), pp. 1-31, ISSN 0009-2665

Lyamichev, V., Frank-Kamenetskii, M., Soyfer, V. Protection against UV-induced pyrimidine dimerization in DNA by triplex formation. Nature, Vol.344, No. 6266, (1990), pp. 568-570, ISSN 1476-4687 
Martirosova, E., Karpekina, T., El'-Registan, G. Enzyme modification by natural chemical chaperons of microorganisms. Microbiology, Vol.73, No.5, (August 2004), pp. 609615, ISSN 1350-0872

Mulyukin, A., Soina, V., Demkina, E., Kozlova, A., Suzina, N., Dmitriev, V., Duda, V., ElRegistan, G. Formation of resting cell by non-spore-forming microorganisms as a strategy of long-term survival in the environment. Proceeding of the SPIE. Vol.4939, (January 2003), pp. 208-218, ISSN 0277-786X

Mulyukin, A., Vakhrushev, M., Strazhevskaya, N., Shmyrina, A., Zhdanov, R., Suzina, N., Duda, V., El-Registan, G. Effect of alkylhydroxybenzens, microbial anabiosis inducers, on the structural organization of Pseudomonas aurantiaca DNA and on the induction of phenotypic dissociation. Microbiology, Vol.74, No.2, (March 2005), pp. 128-135, ISSN 1350-0872

Nikolaev, Yu., Mulyukin, A., Stepanenko, I., El-Registan, G. Autoregulation of the stressful answer of microorganisms. Microbiology, Vol.75, No.4, (June 2006), pp. 489-496, ISSN 1350-0872

Petrovskii, A., Loiko, N., Nikolaev, Yu., Kozlova, A., El'-Registan, G., Deryabin, D., Mikhailenko, N., Kobzeva, T., Kanaev, P., Krupyanskii, Yu. Regulation of the function activity of lysozyme by alkylhydroxybenzenes. Microbiology, Vol.78, No.2, (March 2009), pp. 144-153, ISSN 1350-0872

Reusch, R., Sadoff, H. Novel lipid components of the Azotobacter vinelandii cyst membrane. Nature, Vol. 302, (1983), pp.268-270, ISSN 1476-4687

Rosen, R., Davidov, Y., LaRossa, R., Belkin, S. Microbial sensors of ultraviolet radiation based on recA'::lux fusions. Applied Biochemistry and Biotechnology, Vol.89, No.2-3, (2000), pp. 151-160, ISSN 1559-0291

Setlow, P. Mechanisms for the prevention of damage to the DNA in spores of Bacillus species. Annual Review of Microbiology, Vol.49, (1995), pp. 29-54, ISSN 0066-4227

Solyanikova, I., Konovalova, E., El-Registan, G., Golovleva, L. Effect of alkylhydroxybenzenes on the properties of dioxygenases. Journal of Environmental Science and Health, Part B. Vol.45. (2011), pp. 810-818, ISSN 1001-0742

Sosa, A., Pupo, E., Casalvilla, R., Fernandez-Patron, C. Zinc-imidazole positive: a new method for DNA detection after electrophoresis on agarose gels not interfering with DNA biological integrity. Electrophoresis, Vol.17, No.1, (January 1996), pp. 26-29, ISSN 1349-9394

Stepanenko, I., Strakhovskaya, M., Belenikina, N., Nikolaev, Yu., Mulyukin, A., Kozlova, A., Revina, A., El'-Registan, G. Protection of Saccharomyces cerevisiae against oxidative and radiation-caused damage by alkylhydroxybenzenes. Microbiology, Vol.73, No.2, (March 2004), pp. 204-210, ISSN 1350-0872

Suzina, N., Dmitriev, V., Shorokhova, A., Duda, V., Mulyukin, A., Nikolaev, Y., Bobkova, Y. Barinova, E., Plakunov, V., El-Registan, G. The structural bases of long-term anabiosis in non-spore-forming bacteria. Advances in Space Research, Vol.38, No.6, (2006), pp. 1209-1219, ISSN 0273-1177

Tsvetkova, N., Golyasnaya, N. Induction of SOS-response in Escherichia coli under conditions of osmotic stress and in the presence of N-methyl-N'-nitro-N- 
nitrosoguanidine. Microbiology, Vol.76, No.4, (June 2007), pp. 448-455, ISSN 13500872

Vagel, A., Roo, E. Alkylresorcinols - rare chemicals available in bulk. Innov. Pharm. Tech. (2004), pp. 94-95

Zarnowski, R., Kozubek, A., Pietr, S. Effect of rye 5-n-alkylresorcinols on in vitro growth of phytopathogenic Fusarium and Rhizoctonia fungi. Bulletin of the Polish Academy of Sciences, Vol.47, No.2-4, (1999), pp. 231-235, ISSN 0239-7269 


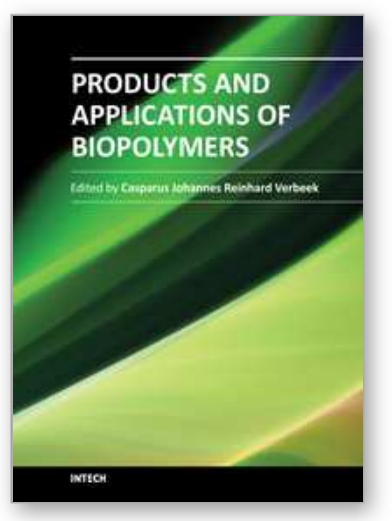

\author{
Products and Applications of Biopolymers \\ Edited by Dr. Johan Verbeek
}

ISBN 978-953-51-0226-7

Hard cover, 220 pages

Publisher InTech

Published online 07, March, 2012

Published in print edition March, 2012

It is interesting to consider that biopolymers are by no means new to this world. It is only because of our fascination with petrochemical products that these wonderful materials have been neglected for so long. Today we face a different challenge. Environmental pressure is pushing away from synthetic or petro-chemically derived products, while economic factors are pulling back from often more expensive "green" options. This book presents two aspects of biopolymers; potential products and some applications of biopolymers covering the current relevance of biopolymers.

\title{
How to reference
}

In order to correctly reference this scholarly work, feel free to copy and paste the following:

Dmitry Deryabin, Olga Davydova and Irina Gryazeva (2012). Alkylresorcinols Protect the DNA from UVDamage In Vitro and In Vivo Models, Products and Applications of Biopolymers, Dr. Johan Verbeek (Ed.), ISBN: 978-953-51-0226-7, InTech, Available from: http://www.intechopen.com/books/products-andapplications-of-biopolymers/alkylresorcinols-protect-the-dna-from-uv-damage-in-vitro-and-in-vivo-models

\section{INTECH}

open science | open minds

\section{InTech Europe}

University Campus STeP Ri

Slavka Krautzeka 83/A

51000 Rijeka, Croatia

Phone: +385 (51) 770447

Fax: +385 (51) 686166

www.intechopen.com

\section{InTech China}

Unit 405, Office Block, Hotel Equatorial Shanghai

No.65, Yan An Road (West), Shanghai, 200040, China

中国上海市延安西路 65 号上海国际贵都大饭店办公楼 405 单元

Phone: +86-21-62489820

Fax: +86-21-62489821 
(C) 2012 The Author(s). Licensee IntechOpen. This is an open access article distributed under the terms of the Creative Commons Attribution 3.0 License, which permits unrestricted use, distribution, and reproduction in any medium, provided the original work is properly cited. 